AperTO - Archivio Istituzionale Open Access dell'Università di Torino

\title{
Anarchism and urban planning
}

\section{This is the author's manuscript}

Original Citation:

Availability:

This version is available http://hdl.handle.net/2318/1795267

since 2021-07-28T18:17:01Z

Publisher:

Wiley

Published version:

DOI:10.1002/9781405165518.wbeosa088.pub2

Terms of use:

Open Access

Anyone can freely access the full text of works made available as "Open Access". Works made available under a Creative Commons license can be used according to the terms and conditions of said license. Use of all other works requires consent of the right holder (author or publisher) if not exempted from copyright protection by the applicable law. 


\title{
ANARCHISM AND URBAN PLANNING
}

\author{
Alberto Vanolo
}

Manuscript for Encyclopedia entry; final version published as:

Vanolo A. (2019), "Anarchism and urban planning", in G. Ritzer and C. Rokek (eds.), Cities are not products", The Blackwell Encyclopedia of Sociology; DOI: 10.1002/9781405165518.wbeosa088.pub2

\section{Keywords}

Anarchism; anarchist geographies; autonomy; garden city; post-anarchism; urban planning

Anarchy is a philosophy whose core value is the opposition to ideas of authority, hierarchy, domination, exploitation, and ruling. Anarchy includes a vast and variegated universe of different theories, practices, political visions, and projects, and it is possible to name a number of different subcategories including, for example, individual anarchism, collectivist anarchism, anarchist-communism, pacifist anarchism, insurrectionary anarchism, or post-anarchism. These different strands of anarchism share the desire for eliminating authoritarian, coercive, and repressive structures and relations, including capitalism and the state. A pivotal argument of social anarchists is that co-operation, mutual aid, and sociospatial networks offer alternatives to utilitarianism and competition for the organization of collective life and for privileging human relations in regulating social phenomena.

Anarchic arguments and views have had major implications for geography, urbanism, and spatial thinking in general, and it is not a coincidence that two major authors in the history of anarchism, Élisée Reclus (1830-1905) and Peter Kropotkin (1842-1921) were geographers. They both assumed that land use, human settlements, and built environments may have a role in transforming social, economic, and ecological relationships, which is a position that shares many perspectives with urban planning (Breitbart, 2009; Crouch, 2017). Among relevant anarchic ideas about space and politics, decentralization and self-government must be mentioned, originally advocated by intellectuals such as Alexis de Tocqueville and Pierre-Joseph Proudhon. Particularly, Kropotkin elaborated decentralism as a spatial pattern based on federations of autonomous associations, villages, and urban neighborhoods, allowing communal development and the voluntary, reciprocal exchange of goods, ideas, art, knowledge, experiences, and ways of life. In his vision, mutual aid and common benefit may be driving forces in communities, an idea quite at odds with the Darwinist and colonialist perspectives that dominated social sciences and geography at that time. Anarchist ideas have been also innovative in conceptualizing relations between the social and the environmental spheres. In a pioneering way, Reclus developed a kind of systemic understanding of natural and social phenomena, by intending land 
and living beings as inseparable, and the earth as a singular whole. Today, it is widely recognized in academia that the contributions of anarchist intellectuals have had paramount importance in the development of geography, and particularly critical geography (Cook and Norcup, 2012; Springer, 2016) and ecological thinking, most notably in Murray Bookchin's conceptualization of social ecology.

Historically, different forms of large-scale anarchist organisations and autonomist projects took form in a number of places; popular examples include the Paris Commune in 1871, the Free Territory during the Ukrainian Revolution in 1917-1921, the Spanish autonomous communities of the late nineteenth and early twentieth centuries, or the Rebel Zapatista Autonomous Municipalities in Mexico since 1994. However, beyond these celebrated cases, a number of anarchic communities, experiences, and practices have taken and still take form in the world, and various anarchic ideas influenced, and still influence, autonomy projects and forms of communal living which are not strictly or formally connected to anarchism, such as, for example, the kibbutz movement in Israel, or the Freetown of Christiania in Copenhagen.

Urban planning has also been influenced by anarchism. It may be argued that conventional understandings of planning, insisting on ideas of imposed order (Sennett, 1970) can hardly be conjugated with the anarchic opposition to hierarchy and authority, but anarchic sentiments and ideas still influenced various urban planners and utopian urban projects. Many planners have been fascinated by the anarchist project of bypassing the state as an organizational principle by promoting the formation of autonomous, self-governed units of associated labor, organized on co-operative principles and linked to larger networks on the basis of Pierre-Joseph Proudhon's idea of the federation. In these spatial patterns, social control is assumed to take form within the community, occurring spontaneously through the practices of fair exchange and mutual aid, without state authority.

A relevant example of application of these orientations in the sphere of urban planning is represented by the Garden City movement, founded by Ebenezer Howard (1850-1928). Garden cities were urban schemes based on self-contained communities and greenbelts, promoting metropolitan decentralization and a harmonic distribution of housing, industries, and agricultural activities. Examples of garden cities may be easily found in different areas of the world, and particularly in northern Europe and North America. Prominent planners, like Patrick Geddes (1854-1932), one of the conceptual fathers of organic perspectives in urban planning, have also been explicitly influenced by the Garden City movement and by the classic works of Proudhon, Kropotkin, and Reclus: His idea of combining industrial and agricultural activities in urban spaces in order to deal with the problem of limited resources took form in his innovative plan for Tel Aviv, presented in 1925. Anarchist ideas have also been explicitly embraced by Paul and Percival Goodman in their book Communitas, published in 1947, which develops critical arguments about the role of the built environment in sustaining communality and by supporting decentralization and the refusal of externally imposed urban designs, particularly by proposing innovative urban plans for Manhattan and Long Island.

A key author explicitly working on the intersections between anarchism and planning was Colin Ward (1924-2010), whose influence on anarchist thinking has been huge. Among the various arguments developed by Ward, are anarchist solutions to the problems of planning regulation; the do-it-yourself culture in urban development; strategies for encouraging young people and adults to become active agents in the production of urban space; and tactics for reclaiming 
urban space, including squatting and tenant co-operatives. Colin Ward also analyzed the role of architecture as a strategic tool for promoting people-oriented solutions to the problems of housing and participation, as epitomized by architectural projects such as the self-built housing systems proposed by Walter Segal (1907-1985), or the inclusive approaches to architecture proposed by Giancarlo De Carlo (1919-2005).

Anarchism also influenced the well-known experiences of the avant-garde Situationist International (1957-1972), and most notably the works of Guy Debord and other scholars who developed the idea of psychogeography. The Situationist International artistic and political movement aimed at destabilizing and criticizing advanced capitalism and its related cultures by mobilizing "diverse" everyday experiences, blending play, spontaneity, art, mobilization, and critical thinking in the city. Although the Situationist International is not an anarchic movement in a strict sense, it shares common influences with anarchism, and they influenced each other in meaningful ways, as well as in the case of other avant-garde movements, such as surrealism.

The relevance of anarchism in the urban sphere has become evident in the 1990s with the diffusion of global justice and resistance movements, autonomist projects, and anticapitalist campaigns (Routledge, 2003). Many autonomous spaces, intended as experiments in nonhierarchical organization and consensus-based decision-making, have been often developed out of anarchic ideals of decentralization, with the aim of creating forms of political, social, and economic organization - beyond nation-states, international financial institutions, global corporations, and neoliberalism - oriented toward solidarity and equality (Pickerill and Chatterton, 2006; Newman, 2011). Hakim Bey's idea of temporary autonomous zones (TAZs), intended as sites free of hierarchical control, encouraging imaginative and experimental uses of space, fits in this framework.

Most recently, anarchist ideas have been renewed with the infusion of poststructuralist ideas and labeled as post-anarchism (Rousselle and Evren, 2011; Springer, 2016). The intellectual influence of anarchism and post-anarchism on urbanism and development is in line with recent works exploring alternatives to actual hegemonic models and visions. Among these, it is possible to mention Gibson-Graham's work on diverse economies and community economies (GibsonGraham, 2006), recent debates on food sovereignty (Hopma and Woods, 2014), radical approaches to social and political ecology (Newman, 2011), and anarchist queer geographies (Rouhani, 2012).

\section{References}

Breitbart, M. M. (2009) Anarchism/anarchist geography, in International Encyclopedia of Human Geography, vol. 1 (ed. R. Kitchin and N. Thrift), Elsevier, Oxford, pp. 108-115.

Cook, I.G. and Norcup J. (2012) Geographies and urban space, in The Continuum Companion to Anarchism (ed. R. Kinna), Continuum, London, pp. 278-298.

Crouch, D. (2017) Lived spaces and planning anarchy: theory and practice of Colin Ward. Planning Theory \& Practice, $18,684-689$.

Gibson-Graham, J.K. (2006) The End of Capitalism (As We Knew It): A Feminist Critique of Political Economy, University of Minnesota Press, Minneapolis, MN. 
Goodman, P. and Goodman, P. (1947) Communitas: Means of Livelihood and Ways of Life, University of Chicago Press, Chicago, IL.

Hopma, J. and Woods, M. (2014) Political geographies of "food security" and "food sovereignty." Geography Compass, 8, 773-784.

Newman, S. (2011) Postanarchism and space: revolutionary fantasies and autonomous zones. Planning Theory, 10, 344-365.

Pickerill, J. and Chatterton, P. (2006) Notes towards autonomous geographies: creation, resistance and self-management as survival tactics. Progress in Human Geography, 30, 730-746.

Rouhani, F. (2012) Anarchism, geography, and queer space-making: Building bridges over chasms we create. ACME: An International Journal for Critical Geographies, 11, 373-392.

Rousselle, D. and Evren, S. (eds) (2011) Post-Anarchism: A Reader, Pluto Press, London.

Routledge, P. (2003) Convergence space: process geographies of grassroots globalisation networks. Transactions of the Institute of British Geographers, 28, 333-349.

Sennett, R. (1970) The Uses of Disorder: Personal Identity and City Life, Faber \& Faber, New York.

Springer, S. (2016) The Anarchist Roots of Geography: Toward Spatial Emancipation, University of Minnesota Press, Minneapolis, MN.

\section{Further Readings}

Amster, R., DeLeon, A., Fernandez, L., et al. (eds) (2009) Contemporary Anarchist Studies: An Introductory Anthology of Anarchy in the Academy, Routledge, London.

Ferretti, F. (2017) Evolution and revolution: anarchist geographies, modernity and poststructuralism. Environment and Planning D: Society and Space, 35, 898-912.

Harvey, D. (2017) "Listen, anarchist!": a personal response to Simon Springer's "Why a radical geography must be anarchist." Dialogues in Human Geography, 7, 233-250.

Pinder, D. (2013) Vision of the City: Utopianism, Power and Politics in Twentieth-Century Urbanism, Routledge, London.

Ward, C. (2004) Anarchism: A Very Short Introduction, Oxford University Press, Oxford. 